\title{
Floral Morphology of Cuscuta reflexa Roxb. and C. lupuliformis Krocker with a Brief Review of the Literature on the Genus Cuscuta
}

\author{
by *Brahmadatta TIAGI
}

Received October 25, 1965

The genus Cuscuta, consisting of about 120 species is almost cosmopolitan in its distribution ${ }^{1)}$. They are leafless, twining, herbaceous total stem-parasites. Most of the species are annual but some are perennial, perennating by various interesting means $^{2-6)}$. Cuscuta species or dodders as they are commonly called are obnoxious weeds causing considerable damage to various crops in many countries ${ }^{7)}$. The dodders are usually called by a number of fanciful names such as love-vine, strangleweed, devil's-hair, and gold-thread.

\section{Review of the Literature}

Kott $^{8)}$ found that certain dodders become parasitic on other dodder species or on plants of their own species, without any harmful effects on them. However, complex host-parasitic relationships are established when Cuscuta becomes parasitic on other parasitic plants such as Euphrasia, Melampyrum, Orobanche, and Odontites. Some species of Cuscuta produce galls on the infected stems ${ }^{9)}$. Cuscuta americana galls on the branches of lime simulate those caused by the fungus Sphaeropsis tumefaciens on lime ${ }^{10)}$.

Cuscuta has attracted the attention of plant morphologists, taxonomists, pathologists, and physiologists. Embryologically the genus is quite well known ${ }^{11-14)}$. Gaertner ${ }^{15)}$ made an excellent study of seed germination, seed identification, and host relationships in dodders. Fujita ${ }^{16)}$ described phyllotaxis in Cuscuta seedlings which is distichous initially, becoming spiral later. He designates this as Cuscutatype of Phyllotaxis. Cutter ${ }^{17)}$ made an anatomical study of the shoot apex of some parasitic and saprophytic angiosperms including two species of Cuscuta, and concluded that there is no anomaly of shoot apical organisation associated with irregular nutrition.

Kamensky ${ }^{18)}$ emphasized the systematic value of the anatomical structure of the seed of Cuscuta in identification. Similarly Mitrofanova ${ }^{19}{ }^{20)}$ indicated some constant taxonomically useful structural features of the embryo and seed of Cuscuta. Several monographs have been published on the taxonomy of the genus ${ }^{21,22}$. In India, Santapau and Patel ${ }^{23)}$ studied the genus as occurring in Bombay. The genus is divided into three subgenera-Eucuscuta, Monogynella, and Cleistogrammica ${ }^{22}$.

Plant pathologists have used Cuscuta as a living conducting tissue for transmitting virus from one plant to another. This envisages the transfer of a virus to a wider range of hosts than would be possible by grafting ${ }^{24)}$. Smolak ${ }^{25)}$ reported dodder as a vector of plant viruses.

Lane and Kasperbauer ${ }^{26)}$ studied photomorphogenic responses of dodder seedlings and found the controlling photoreactions causing hook opening and twining. Macleod ${ }^{27)}$

* Department of Botany, University of Rajasthan, Jaipur, India. 
showed that due to the presence of cholorophyll, carbon-di-oxide fixation occurs in Cuscuta campestris and C. reflexa. Tronchet ${ }^{28,29)}$ observed periodical variations of fresh weight of Cuscuta gronovii seedlings and indicated a possibility of existence of an endogenous rhythm. $\mathrm{Loo}^{30)}$ cultured excised stem-tip of dodder in vitro. Baldev $^{31,32)}$ observed in vitro responses of growth and development of the shoot apices of Cuscuta reflexa. He induced off-season flowering, leading to the development of parthenocarpic fruits in vitro. Maheshwari and Baldev ${ }^{33)}$ cultured embryos of Cuscuta reflexa which gave rise to adventive embryos that developed into normal shoots.

It is clear from the above account that the floral morphology of Cuscuta has not been given the due attention so far. An attempt has been made therefore, to present the floral morphology of Cuscuta reflexa and C. lupuliformis belonging to the subgenus Monogynella.

\section{Material and Methods}

The material of Cuscuta reflexa was collected locally; C. Iupuliformis was obtained through the courtesy of the Director, University botanical garden, Copenhagen. The flowers were processed through alcohol-xylol series for embedding in paraffinwax. Sections were cut at ten to fifteen microns thickness and stained with safranin-fast green, and crystal violet -erythrosin combinations; the latter gave better results.

\section{The Flower}

The flowers are clustered in short racemes in Cuscuta reflexa, and in globular heads in C. lupuliformis. They are shortly stalked in the former and almost sessile in the latter. The five sepals are subequal and connate at the base. The corolla tube with five reflexed segments is almost cylindrical. It bears a ring of scales which are fimbriate in Cuscuta refiexa. The five epipetalous stamens are inserted at the throat of the corolla tube. Their filaments are short and bracket-shaped and the anthers are partially exserted. Gynoecium is ovoid in shape, imperfectly twocelled with two ovules in each locule. The fleshy fruit is a globose, circumcissile capsule. The seeds are triangular, with fleshy endosperm and the embryo is slender, spirally coiled. It is without any cotyledons but with a few scale leaves ${ }^{16)}$. The ovary is narrowed upwards into a single short and thick style with two-lobed stigmas; the style is almost absent in Cuscuta reflexa.

\section{The Thalamus and the Sepaline Supply}

The stele of the thalamus is made up of about ten discrete, collateral and radially elongated vascular bundles (Fig. 4, 5). The phloem is in abundance while the xylem is weakly developed. There are about ten to fifteen bundles when the traces for the sepals emerge from the stele (Fig. 6).

The sepals: The sepals possess an unbranched, feeble vascular bundle which fades almost half-way up in the sepal. The bases of the sepals are fused together to form a massive ring (Figs. 8, 9). They separate into individual sepals of unequal size at the level of the base of the ovary (Figs. 10,11,14). The apex and margins of a sepal are thin and membranous. They are made up of large parenchymatous cells, enclosing small air spaces (Figs. 33, 34). In Cuscuta lupuliformis, thick walled, 
reticulate and pitted cells (Fig. 35) occur in the cortex and pith of the thalamus and these continue in the sepals. These sclereids are arrranged in the sepals in series, converging toward the apex. A thick cuticle, thrown into linear folds (Fig. 40) covers the epidermis of the sepals (Figs. 33, 34). The inner tangential walls and partly the radial walls of the inner epidermis are thickened. The sepals extend upto the apex of the ovary.

\section{The Petaline and Staminal Supply}

The traces for the petals emerge alternate to the sepaline bundles. The petaline bundles are feeble and unbranched (Figs. 7-9). The staminal traces, alternating the petaline bundles, however, are better developed (Fig. 7). The petaline bundles remain within the corolla tube (Figs. 9-11, 14) until the insertion of the anthers (Fig. 28). The petaline and staminal bundles may be easily distinguished from each other; the former being much feebler than the latter.

The corolla tube and the stamens: The corolla tube is made up of five to eight layers of large parenchymatous cells enclosing small air spaces (Figs. 36-39). The outer and inner epidermis is well differentiated in the distal region of the tube (Figs. 36, 38); the inner being more conspicuous. The inner epidermis of the corolla tube in the stigmatic region consists of glandular, richly protoplasmic, buldged out cells, having large nuclei and a thick cuticle (Fig. 38). The corolla below the insertion of the anthers may bear lobed protuberances on the protruding staminal filaments. These are simple or lobed and often bear glandular organs (Fig. 30) of various shapes. Above the insertion of the anther, the corolla tube segments into five lobes. The anthers are borne on small bracketlike filaments (Fig. 28). The staminal supply ends abruptly in the distal region of the anther. Gum cells occur abundantly in the hypodermal position in the corolla lobes. These are also found in the anther connective surrounding the amphicribral vascular bundle (Fig. 28).

The staminal scales: Nonvascular scales occur at the bases of the stamens. They are completely merged with the corolla tube at the base but are separated due to the appearance of tangential cavities over the petaline bundles (Fig. 17). The scales also begin separating from the adjacent ones as the corolla tube widens just above the level of the attachment of the ovules in the ovary (Figs. 17, 22). They conceal below their free margins, variously shaped glands (Figs. 29, 31, 32). The lateral marginal cells of the scales draw out into hairy processes which intertwine to form glandular processes (Figs. 24, 27). The scales are partly fused with the corolla tube but become free at the level of the base of the style (Fig. 27). They extend, however, upto the stigmatic region. In contrast to Cuscuta lupuliformis (Fig. 23) the scales are more prominent, having fimbriate margins in C. reflexa (Fig. 22).

\section{The Disc}

An annular disc appears inside the corolla tube (Figs. 9-11). It consists of large parenchymatous cells having prominent nuclei and dense vacuolated cytoplasm (Fig. 43). The disc is not sharply demarcated since it merges imperceptibly with the more central receptacular tissue. The epidermis of the disc is in line with the outer epidermis of the ovary wall; the latter being situated just above and over the disc. In between the disc and the ovary wall, there is a meristematic zone around, which adds to the growth of the ovary wall. The fruit also dehisces in this region in a circumscissile manner. 


\section{Gynoecium and its Vascular Supply}

Some feeble bundles are left scattered in the receptacular tissue after the sepals, petals and the stamens have received their vascular supply (Figs. 8, 9). Most of them move around to the periphery, passing through the disc and constituting the vascular supply of the ovary wall (Figs. 10,11). These traces are more clearly visible in Cuscuta lupuliformis (Fig. 10) because the disc is less opaque in this species. The remaining ones arrange themselves in a ring of feeble bundles (Figs. 12, 13). This ring constitutes the supply of the placenta and the carpellary septum.

As the locules appear, two of the bundles that had entered in the ovary wall become rather prominent in the antero-posterior position as the carpellary dorsals (Fig. 12). They appear to remain unbranched in the ovary wall. There are however, about eight to ten bundles in each half of the ovary wall; a pair usually being just outside the septum on each side (Figs. 12-20).

The stelar ring destined to supply the ovules gives out traces on both sides of the carpellary septum (Fig. 13). Thus, the ring is resolved into two arc-shaped structures. Just before the insertion of the ovules, the two arcs split up and become condensed, each into two uninverted bundles (Fig. 14) as ventrals (Fig. 14), which diverge outward to supply the ovules (Figs. 15-18). As the ovular supply is being organised, the placental tissue, filling up the entire ovarian chamber in this region (Figs. 15, 16) dwindles and is gradually replaced by obturators (Figs. 17-19). The placental epidermal cells elongate, their walls become mucilaginous, their nuclei hypertrophied, and these intertwine to form the tissue of the obturator which forms canopy over the micropyles of the inverted ovules (Fig. 1, 3). The septum is incomplete in the centre (Fig. 19) but the placental tissue from the floor of the ovary plugs the interrupted portion of the septum (Figs. 1-3). Afterwards, however, the epidermal cells of the septal margins draw out and produce a glandular tissue, simulating the tissue of the obturator, and it fits in between the carpellary margins in order to complete it (Figs. 22, 23). This tissue continues upto the stigma and serves as the transmitting tissue for the advance of the pollen tubes (Figs. 1, 2). In the upper region of the ovary the septum becomes continuous and the transmitting tissue rather compacted (Figs. 20, 21), This tissue consists of cells with mucilaginous walls, enclosing small intercellular spaces, and there is a larger central space which indicates the area where the carpellary margins have not occluded fully.

Figs. 1-21 (Cuscuta reflexa, Figs. 4, 6-9, 11, 14, 15, 17, 19, 20; rest of C. lupuliformis). Fig. 1. L. s. flower across septum, vascular supply to various organs; note staminal scales. Fig. 2. L.s. through septum, ovary, transmitting tissue. Fig. 3. Same, through locule. Figs. 4, 5. T.s. flower, receptacle. Fig. 6. Same, sepaline traces. Figs. 7, 8. Same, sepaline, petaline and staminal vascular supply. Figs. 9-11. Same, calyx and corolla; stelar bundles migrating in disc. Figs. 12, 13. T. s. ovary, carpellary supply. Fig. 14. T.s. flower, fully organised vascular supply. Figs. 15, 16. T.s. ovary, ventral bundles diverging, placental tissue filling ovarian chambers. Figs. 17, 18. T.s. flower, carpellary supply, ovules, obturator, and placental tissue; note cavities in corolla tube separating staminal scales in Fig. 17. Fig. 19. T. s. ovary, ovules, obturator, incomplete septum; Fig. 20. Same, ovules, complete septum with transmitting tissue. Fig. 21. T.s. flower, corolla tube and scales, carpellary supply, complete septum, thickenings in inner hypodermal layer of ovary. All figures $\times 15$. ( $A=$ staminal supply; $C=$ petaline supply; $C a=$ cavity in corolla tube; $\mathrm{D}=$ carpellary dorsal; $\mathrm{Dc}=$ disc; $\mathrm{K}=$ sepaline supply; $\mathrm{O}=$ ovary wall supply; $\mathrm{Ob}$ =obturator; $\mathrm{Ov}=$ ovule; $\mathrm{S}=$ septal supply; $\mathrm{Sc}=$ scale; $\mathrm{T}=$ thickenings; $\mathrm{Tt}=$ transmitting tissue; $\mathrm{V}=$ carpellary ventral). 


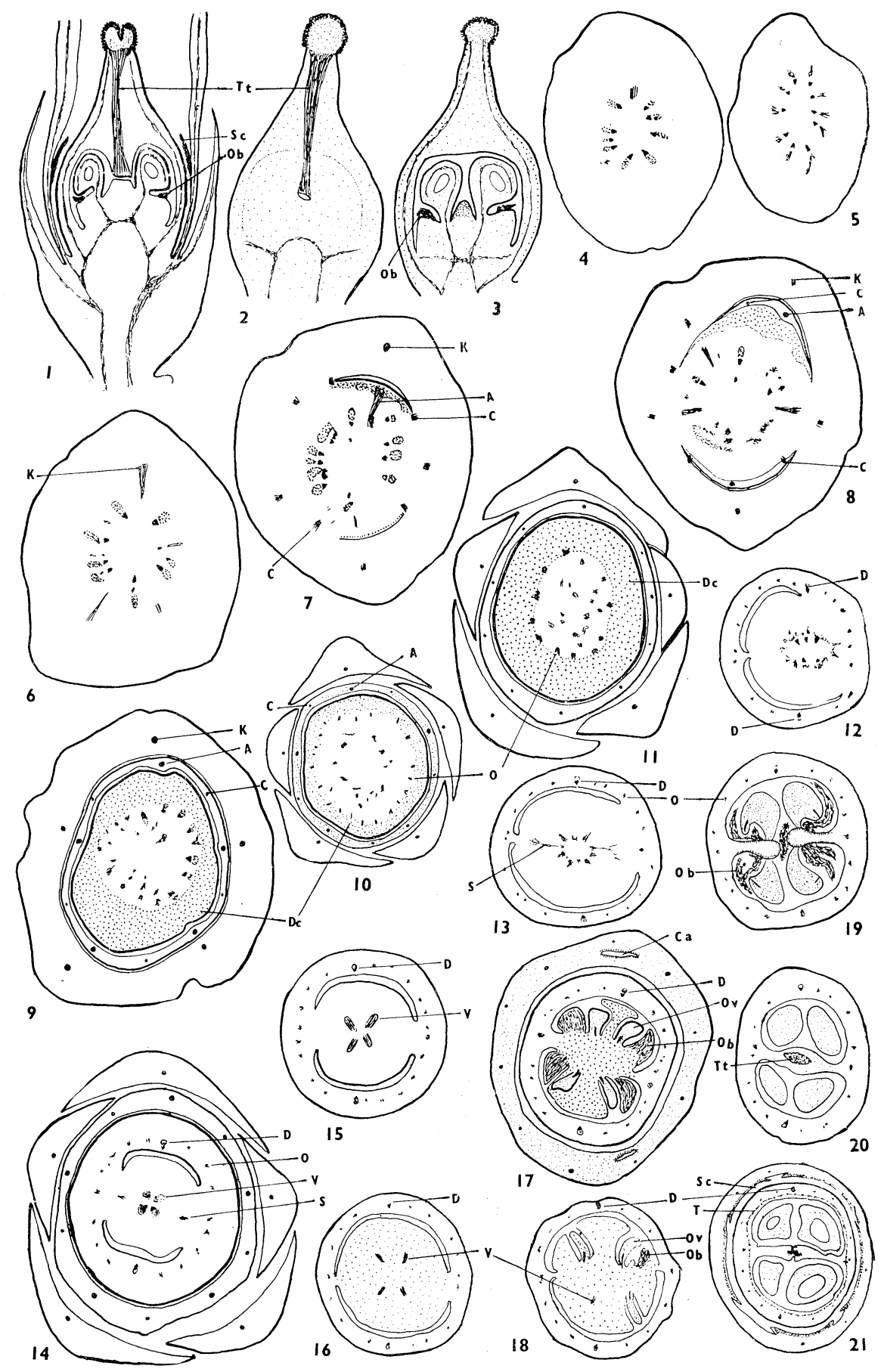




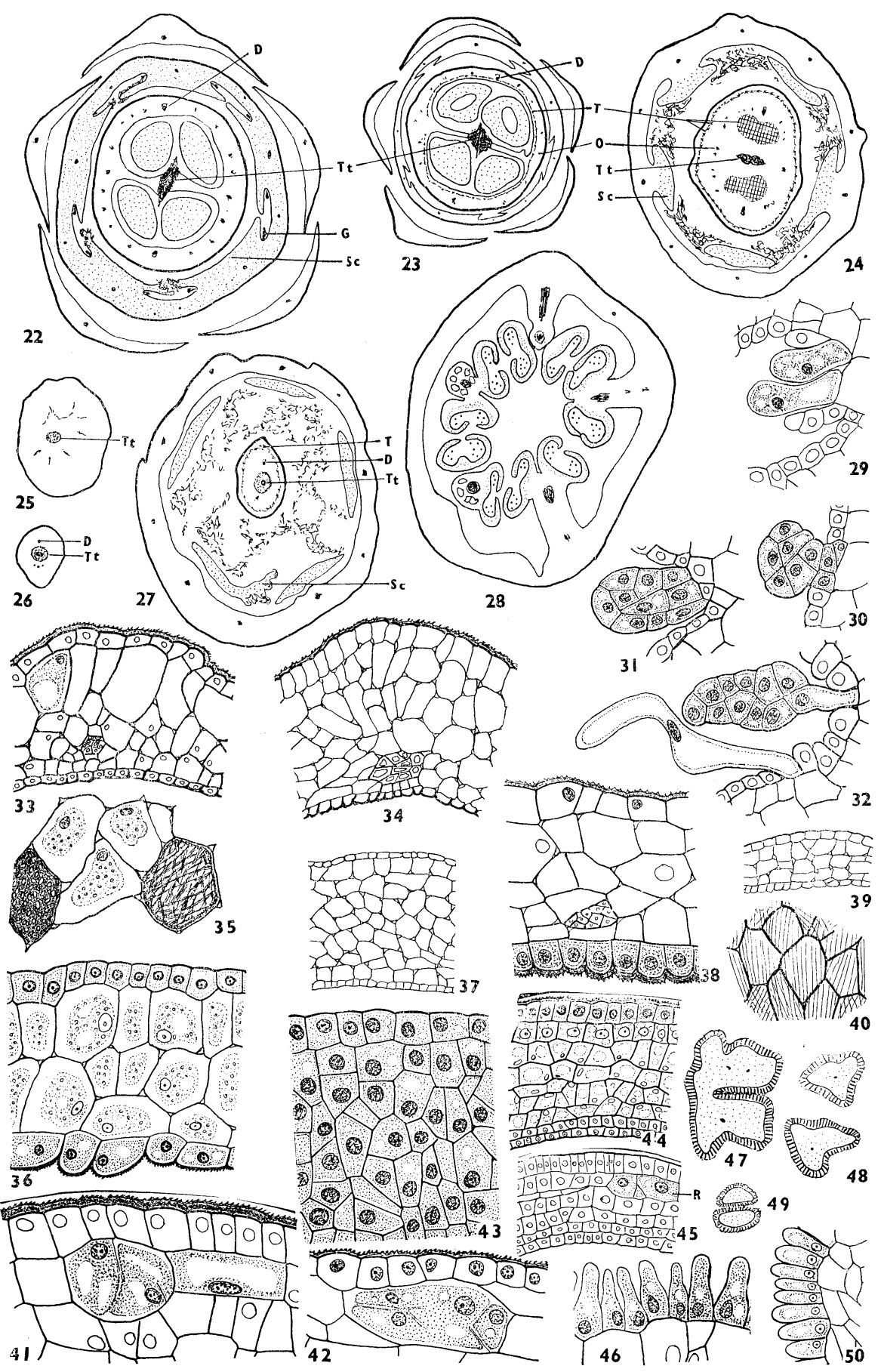


At the base of the style the transmitting tissue is surrounded by the carpellary dorsals and some more bundles of the ovary wall (Fig. 24). However, only the dorsals continue upward in the style (Figs. 25-27). The bifurcated stigma (Figs. 47, 48) bears flask-shaped, glandular epidermal cells in Cuscuta reflexa (Fig. 46). The stigmatic epidermal cells are more compacted and palisadelike in C. lupuliformis (Figs. 49, 50).

The ovary wall: The ovary wall is about eight layered in Cuscuta reflexa (Fig. 44) and six layered in C. lupuliformis (Fig. 45). The outer and the inner epidermis, and the inner hypodermis is well differentiated in both the species. The inner hypodermal cells develop lignified thickenings (Figs. 21, 23, 24). The cells of the outer hypodermis enlarge and become densely cytoplasmic, highly vacuolated, showing prominent nuclei (Figs. 41, 42). These are the resinous or gum cells ${ }^{13,14}$ In the middle and upper region of the ovary wall, the gum cells may also appear in the hypodermal positions as well. As they enlarge, the intervening walls between them may dissolve away, coalescing the protoplasts.

\section{Discussion and General Remarks}

It is perhaps due to the parasitic mode of life of Cuscuta that there has been a general reduction in its tissue systems. Instead of the usual three, the sepals are one traced. There are indications however, that the lateral traces for the sepals arise conjointly and they bifurcate radially but the traces do never enter the sepal margins. Many of the vascular bundles in the flower are just made up of a few tracheids with an abundance of phloem. Some of the bundles may even consist entirely of phoem. The mechanical tissue present in various organs of the flower, however, amply compensates for the reduced function of the weakly developed xylem. The pith cells of the pedicel and thalamus are thickwalled in Cuscuta reflexa, whereas all the cells of the thalamus are uniformly thickened in C. lupuliformis. The xylem is also better developed and sclereids occur in the thalamus and sepals of the latter species. All the parts of the flower are well protected by a thick cuticle. Cutter ${ }^{17}$ ) also observed that bundles in the young stems of Cuscuta consist solely of phloem, and phloem is the preponderant vascular tissue in the bundles.

The gum cells: The gum cells also seem to compensate for the conducting and mechanical function suffered by the floral organs due to the reduction in xylem. They are arranged in files for an upward translocation of the food materials; when their contents perish, they become thick walled. Further, the empty gum cells appear to make the ovary wall buoyant which after dehiscence may be easily carried

Figs. 22-50 (Cuscuta reflexa, Figs. 22, 24, 27-33, 37-38, 40, 41, 43, 44, 46-48: rest of C. lupiliformis). Figs. 22, 23. T.s. flower, sepals, corolla and staminal scales, ovary and ovules. $\times 15$. Fig. 24. Same, apex of ovary, corolla with scales, carpellary supply and transmitting tissue, thickenings in ovary wall. $\times 15$. Figs. 25, 26. T. s. style, transmitting tissue, dorsal bundles. $\times 15$. Fig. 27. T. s. corolla, staminal scales and style. $\times 15$. Fig. 28 . T.s. corolla, epipetalous stamens. $\times 15$. Figs. 29-32. Glandular bodies. $\times 170$. Figs. 33,34 . T. s. base of sepal. $\times 65$. Fig. 35. Sclereids. $\times 170$. Figs. 36-39. T. s. petal. $\times 65 . \quad$ Fig. 40 . cuticle, surface view. $\times 170$. Figs. 41, 42. T.s. portion of ovary wall, resinous cells. $\times 170$. Fig. 43 T.s. portion of disc. $\times 170$. Figs. 44, 45. Portion of ovary wall. $\times 100$. Fig. 46 . Stigmatic papillae. $\times 170$. Figs. $47-49$. T. s. stigma. $\times 15$. Fig. 50. Stigmatic papillae. $\times 170$. $(\mathrm{D}=$ carpellary dorsal; $\mathrm{G}=$ gland; $\mathrm{O}=$ ovary wall supply; $\mathrm{Sc}=$ staminal scale; $\mathrm{T}=$ thickenings; $\mathrm{Tt}=$ transmitting tissue; $\mathrm{V}=$ carpellary ventral). 
away. It is interesting to note that the gum cells also occur in the upper part of the ovary wall and the anther connective in Evolvulus alsinoides ${ }^{34)}$.

Staminal scales: The present study reveals that histologically the staminal scales are corollalike. Since they harbour under them the glandular bodies, it is likely that they serve as floral nectaries. The scales do not occur in all the species of Cuscuta and they are not reported to be present in other members of the Convolvulaceae ${ }^{35,1)}$ Tiagi and Gupta ${ }^{34)}$ however, found them in a similar situation in Evolvulus alsinoides. The Disc: In the allied families, Solanaceae and Boraginaceae, the disc is formed by the base of the ovary ${ }^{36)}$. In Cuscuta also, the base of the ovary itself serves as a built-in nectary which is quite conspicuous particularly in Cuscuta reflexa in a cross section but is hardly visible as a separate structure in the flower.

Placentation: Anatomically the placentation in Cuscuta is axile, because the placentae are borne on the imperfectly fused margins of the same carpel and they derive their vascular supply from ventrals belonging to the same carpel. Cuscuta also shares some features of the parietal placentation since the ovary in the fertile basal region is almost unilocular and the ventrals are normally oriented although as in axile, they lie almost on the same radii as the dorsals ${ }^{37)}$. In my judgement, therefore, the placentation in Cuscuta although axile, shows a case where it is heading towards parietal placentation. Puri ${ }^{36)}$ believes that parietal placentation in almost all cases has been derived from axile but Eames $^{38}$ thinks that the type commonly called parietal has probably not been derived from axile.

The axile placentation has given rise to the parietal due to a recession of the axile placentae from its original central position to a more peripheral one by retraction of the carpellary margins along with the placentae. In doing so, the placental bundles would remain inverted. This is generally the case when the axile placenta is heading towards parietal. Moreover, some established cases of parietal types such as Crataeva religiosa show the progress from axile to parietal in certain abnormal cases $^{36)}$. Eames $^{38)}$ however, remarks that almost in all cases of parietal placentation, the ventral bundles are normally oriented like the dorsals. He therefore, believes that the parietal placentation is the result of bringing together of margins with the placentae of the open carpels.

\section{Summary}

Cuscuta conforms to the floral formula: K (5), $\overparen{\mathrm{C(5),A}} 5, G(2)$. The thalamus contains ten to fifteen discrete collateral bundles. The sepals, petals, and stamens are one traced each. Phloem is more abundant than xylem in the bundles. Nonvascular staminal scales occur at the bases of the stamens on the corolla tube. The base of the ovary acts as a nectariferous disc. Resinous cells occur in all the organs of the flower especially in the ovary wall. Besides the carpellary dorsals, some more stelar bundles enter the ovary wall. The dorsals continue upto the stigma but the uninverted ventral bundles directly enter into the ovules. The base of the ovarian chamber is filled with a placental tissue which fits in between the receded carpellary margins, thus completing the septum. Placental obturator forms canopy over the micropyles of the inverted ovules.

\section{Acknowledgements}

I am grateful to Professor P. Maheshwari, F. R. S. for encouragement, and to the Director University Botanical Gardens Copenhagen, for the material of C. lupuliformis. 


\section{References}

1) Lawrence, G. H. M., Taxonomy of Vascular Plants (Macmillan, New York, 1950). 2) Rao, Narayana, L., New Phytol. 37: 474 (1938). 3) Schillito, J.F., Watsonia 2: 239 (1952) 4) Dean, H. L., Proc. Iowa Acad. Sci. 61: 99 (1954). 5) Truscott, F. H., Amer. Jour. Bot. 45: 169 (1958). 6) Stojanovic, D., Zashtita Bilja. 51: 47 (1959). 7) Srinivasan, A.R., and Subramanian, C. L., A Review of Literature on the Phanerogamic Parasites (Indian Council of Agricultural Research, New Delhi, 1960). 8) Kott, S. A., Bot. Zhur. 44: 1333 (1959). 9) Dean, H. L., Amer. Jour. Bot. 24: 167 (1937). 10) Knorr, L. C., Phytopath. 39: 616 (1949). 11) Fedortschuk, W., Planta 14: 94 (1931). 12) Smith, B. E., Jour. Elisha Mitchell Sci. Soc. 50: 283 (1934). 13) Tiagi, B., Phytomorphology 1: 9 (1951). 14) Johri, B. M., and Tiagi, B., ibid. 2: 162 (1952). 15) Gaertner, E. E., Mem. 294. Cornell Univ. Agricult. Expet. Stat. Ithaca, New York, 1-56, (1950). 16) Fujita, T., Bot. Mag. Tokyo 77: 73 (1964). 17) Cutter, E. G., Phytomorphology 5: 231 (1955). 18) Kamensky, K. W., Angewandte Bot. 10: 387 (1928). 19) Mitrofanova, N. S., Bot. Zhur. 46: 259 (1961). 20) —- Byull. Moskov. Obsch. Ispytat. Prirody-Otdel. Biol 67: 141 (1962). 21) Engelmann, G., Amer. Jour. Sci. Arts 43: 333 (1842). 22) Yuncker, T. G., Mem. Torrey Bot. Cl. 18: 113 (1932). 23) Santapau, H., and Patel, V., Jour. Bombay Nat. Hist. Soc. 54: 707 (1957). 24) Lackey, C. F., Phytopath. 39: 562 (1949). 25) Smolak, J., Ochrana. Rostlin. 22: 55 (1949). 26) Lane, H.C. and Kasperbauer, M. J., Plant Physiol. 40: 109 (1965). 27) Macleod, D. G., Trans. Proc. Bot. Soc. Edinburgh 39: 302 (1962). 28) Tronchet, J., Ann. Sci. Univ. Besancon Bot. 12: 43 (1958). 29) —_ ibid, 16:1 (1961). 30) Loo, S. W., Amer. Jour. Bot. 33: 295 (1946). 31) Baldev, B., Phytomorphology 9: 316 (1959). 32) —- Ann. Bot. 26: 173 (1962). 33) Maheshwari, P., and Baldev. B., Plant Embriology-A Symposium, Council of Scientific and Industrial Research, New Dehli (1962) 34) Tiagi, B., and Gupta, P. K., Proc. Rajasthan Acad. Sci. 10: 51 (1963). $\quad 35)$ Rendle, A. B., The Classification of Flowering Plants, Vol. 2 Dicotyledons (Univ. Press., Cambridge, 1952). 36) Puri, V., Bot. Rew. 17: 471 (1951). 37) — ibid. 18: 603 (1952). 38) Eames, A. J., Mophology of Angiosperms (McGraw Hill, New York, 1961).

\section{摘要}

Brahmadatta Tiagi; ネナシカズラ属 2 種 Cuscuta reflexa Roxb. と C. lupliformis Krocker の花の形態学的研究

植物分類，形態，生理, 病理などの諸分野にお汓るネナシカズラ属についての研究の概要をのべてこの属 の種々の特異性を明かにしたのち，C. reflexa と C. lupliformis の 2 種の花の外部形態ならびに内部構 造の記述と論議を抏こなった。ネナシカズラ属の花式は $\mathrm{K}(5), \overparen{\mathrm{C}(5), \mathrm{A}} 5, \mathrm{G}(2)$ で示される。花托には10 15 の離在する並立維管束があり，がく片，花びら，おしべにはいずれも 1 本ずつの維管束条が入る。がく片の 維管束はその基部に入る前に 3 維管束の名残りを示すことは注意に值する。抒しべのつけ权にあたる花筒 の内面には維管束のない鱗片がみられ, 子房の基部の花盤はみつ腺としてはたらく。ゴム細胞が花の全器官 にあるが，子房壁にはことに多い。心皮の脊中線をしめる維管束のほか，いく本かが子房壁に入る。春中線 維管束は柱頭まで続くが，その他はそのま肧珠に入る。花托の組織が盛上って子房室を埋め，心皮の縁部 之密接して隔壁を作る。また胎生のオブチュレーターは倒生肧珠の珠孔の上にひさし状にさしでている。胎 座は中軸胎座の範囲にはいるが, 唄膜胎座への移行の兆をみせている。な㧍花盤と子房壁の間には全周をめ ぐる分裂組織があって，子房壁を生長させる。果実（蓋果）は後にこの部分で開裂する。

ネナシカズラ属の花の組織は全般的に退行が著るしいが，これは寄生という特殊な生活様式に関連する 为のと思われる。維管束の木部の発達はことに貧弱で, 僅少の仮道管からできているか, 時には全く欠け る。各所にある原膜組織は木部に代って器械的な役目をおこなう。交た縦方向に連なるゴム細胞は，はじめ 養分の移行にもあずかり，のち内容を失うと厚膜となって器械的な役目をおこならようになる。 (Rajasthan 大学植物学教室) 